\title{
TWO NEW NEMATODE SPECIES OF THE FAMILY DIPLOPELTIDAE FILIPJEV, 1918 (NEMATODA, ARAEOLAIMIDA) FROM COAST OF VIETNAM
}

\author{
Nguyen Vu Thanh ${ }^{1 *}$, Nguyen Thanh Hien ${ }^{1}$, Vladimir G. Gagarin ${ }^{2}$ \\ ${ }^{(1)}$ Institute of Ecology and biological Resources, VAST, ${ }^{*}$ nvthanh49@yahoo.com \\ ${ }^{(2)}$ Institute of Inland waters Biology, Russian Academy of Science, Russia
}

\begin{abstract}
Two new species of free-living marine nematodes from West Sea (Gulf of Siam), coast of Vietnam, were described and illustrated. Diplopeltula obesa sp. n. differs from D. indica Gerlach, 1962 by possessing shorter and thicker body, comparatively longer tail and shorter cephalic setae, Campylaimus gracilis sp. n. resemble to C. minor Timm, 1961, but differs from the later by having an another shape of amphidial fovea, another position of mouth, longer body and shorter cephalic setae.
\end{abstract}

Key words: Araeolaimida, Campylaimus, Diplopeltula free-living marine nematodes, new species, West Sea, coast of Vietnam.

\section{INTRODUCTION}

Fauna of free-living marine nematodes of Vietnam is studied recently. At present, this investigating field on nematode biodiversity is strongly improved, in connection with creating of the new database for the bio-monitoring assessment of water quality in watershed and wetland ecosystems in Vietnam. This work is a part of the Project funding by Vietnam National Foundation NAFOSTED for studying biodiversity of free-living nematode fauna at the coastal areas of the West sea (Gulf of Siam) of Vietnam during 2008-2010.

\section{MATERIAL AND METHODS}

Nematode samples were collected in November 2008 at coast of West sea, Vietnam with latitude $8^{\circ} 35^{\prime} 7.92^{\prime} ' \mathrm{~N}-8^{\circ} 44^{\prime} 22.53^{\prime} ' \mathrm{~N}$ and longitude $104^{\circ} 57^{\prime} 55.05^{\prime}$ 'E - $105^{\circ} 14^{\prime} 10.76^{\prime}$ 'E. Samples were processed on-board using a Ponar grab. In each station one grab was collected with three replications for nematodes analysis, all samples were fixed in hot formalin $10 \%$. The nematodes were extracted by LUDOX-TM 50 solution with centrifugation method and gradually transferred to anhydrous glycerin and finally mounted in permanent slides.

\section{DESCRIPTION}

Order Araeolaimida de Coninck et Schuurmans Stekhoven, 1933

Family Diplopeltidae Filipjev, 1918

\section{Diplopeltula obesa sp. n. (fig. 1)}

Measurements: Table 1.

Female: Body comparatively short and thick. Cuticle coarsely annulated, its thickness at body middle about $1 \mu \mathrm{m}$. Somatic, cervical setae and hypodermal glands absent. Cephalic end narrowed, conic pointed. Lips absent. Mouth opening situated terminally. Stoma not expressed. Labial sensillae not observed. Four cephalic setae in shape of thin and short setae, $1.2 \mu \mathrm{m}$ long. Amphidial fovea loop-shaped, 17 $\mu \mathrm{m}$ long, 1.5 times as long as the diameter of labial region. Amphidial fovea deposited at sclerotized plates, which incorporate among themselves, formed cephalic capsule. Oesophagus weakly muscular, not formed basal bulb. Cardia comparatively large, 4-5 $\mu \mathrm{m}$ long. Renette body, ducts and excretory pore not observed. Rectum 0.7-0.8 times as long as the anal body diameter.

Gonads twin, opposited, outstretched, comparatively short. Anterior ovary situated entirely to right side of intestine, posterior ovary situated to left side of intestine. Vulva in shape of transverse slit, situated approximately in body middle. Vulvar glands not observed. Vagina straight, with weakly muscle, extending to $25 \%$ of the corresponding body diameter. Uterus spacious. Egg measuring $78 \times 25 \mu \mathrm{m}$. Tail elongate-conical. Three caudal glands finish common duct.

Male: Unknown. 
Type locality and habitat: South East Sea coast of South Vietnam. Latitude $8^{\circ} 35^{\prime} 16.49^{\prime}$ 'N , longitude: $104^{\circ} 57^{\prime} 55.05^{\prime \prime} \mathrm{E}, 9 \mathrm{~m}$ from the bank of Goe creek, strong disturbance, depth $3 \mathrm{~m}$, finely silt -1 . Latitude: $8^{\circ} 33^{\prime} 50.25^{\prime}$ 'N, longitude: $104^{\circ} 58^{\prime} 2.07^{\prime}$ 'E, the mouth of the Goe creek, strong disturbance waves, depth $3.8 \mathrm{~m}$, finely silt -2 우.
Type specimens: Holotype, female on slide number 70/III, deposited at the nematode collection of the Institute of Inland Waters Biology, Borok, Russia. Paratype, two females deposited at the nematode collection of the Institute of Ecology and Biological Resources, Vietnam Academy of Science and Technology, Hanoi, Vietnam.
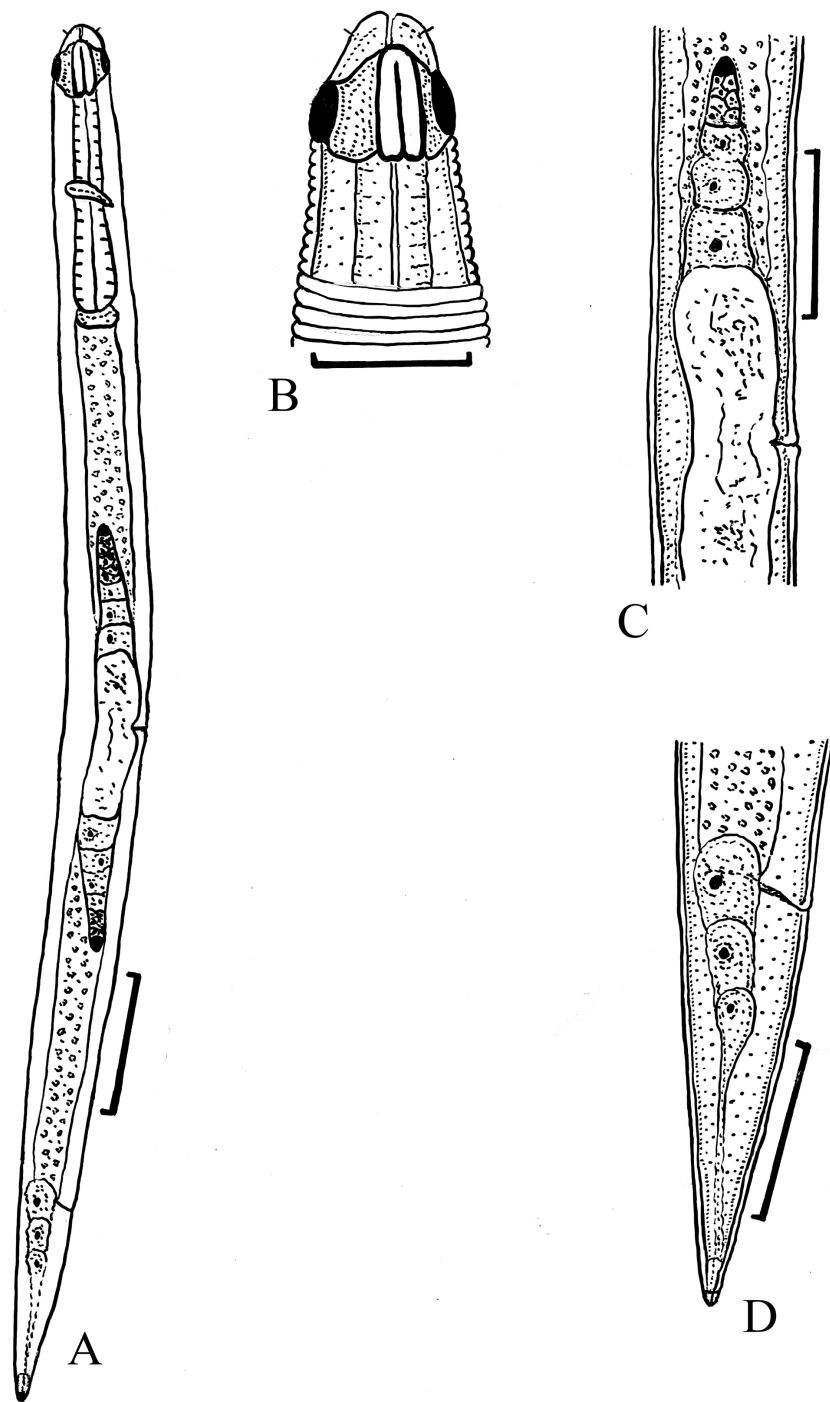

Figure 1. Diplopeltula obesa sp. n. (female)

A. Entire body; B. Head; C. Vulvar region; D. Tail. Scale bars: A - $50 \mu \mathrm{m}$; C, D - $30 \mu \mathrm{m}$; B - $20 \mu \mathrm{m}$.

Differential diagnosis: The new species morphologically resembles to Diplopeltula indica Gerlach, 1962 but it differs from it by having the shorter and thicker body (in $D$. indica $\mathrm{L}=980$ $\mu \mathrm{m}, 1403 \mu \mathrm{m}, \mathrm{a}=36 v s=470-497 \mu \mathrm{m}, \mathrm{a}=17-18$ in new species), comparatively longer tail (in
D. indica $\mathrm{c}=12.3,23.0$ vs $\mathrm{c}=6.8-7.2$ in new species) and shorter cephalic setae 9 (in $D$. indica cephalic setae $9 \mu \mathrm{m}$ long or 0.6 labial region width vs cephalic setae 1.2 long or 0.1-0.2 labial region width in new species) [2].

Etymology: The species name means "obese". 
Table 1. Measurements of Diplopeltula obesa sp. n. (all measurements in $\mu \mathrm{m}$, except ratio)

\begin{tabular}{|l|c|c|}
\hline \multicolumn{1}{|c|}{ Characteristics } & Holotype (+) & 2 paratypes (2 + ) \\
\hline $\mathrm{L}$ & 496 & 497,470 \\
\hline $\mathrm{a}$ & 18 & 18,17 \\
\hline $\mathrm{b}$ & 4.7 & $4.4,4.7$ \\
\hline $\mathrm{c}$ & 7.2 & $7.1,6.8$ \\
\hline $\mathrm{c}^{\prime}$ & 3.3 & $3.5,3.3$ \\
\hline $\mathrm{V}, \%$ & 52.2 & $49.3,51.2$ \\
\hline Head width & 11 & 10,11 \\
\hline Cephalic setae length & 1.2 & $1.2,1.2$ \\
\hline Amphid fovea length & 17 & 17,16 \\
\hline Oesophagus length & 105 & 133,101 \\
\hline Posterior end of oesophagus to vulva & 154 & 133,140 \\
\hline Vulva to anus & 168 & 182,160 \\
\hline Tail length & 69 & 70,69 \\
\hline
\end{tabular}

\section{Campylaimus gracilis sp. n. (fig. 2)}

Measurements: Holotype female: $\mathrm{L}=492$ $\mu \mathrm{m}, \mathrm{a}=21, \mathrm{~b}=6.1, \mathrm{c}=6.2, \mathrm{c}^{\prime}=5.2$, $\mathrm{V}=48.0 \%$. Paratype female: $\mathrm{L}=478 \mu \mathrm{m}$, $\mathrm{a}=24, \mathrm{~b}=6.7, \mathrm{c}=6.7, \mathrm{c}^{\prime}=5.1, \mathrm{~V}=45.6 \%$.

Female: Body comparatively short and thin. Anterior body end strongly narrowed. Cuticle annulated, about $1 \mu \mathrm{m}$ thick in body middle. Somatic setae and hypodermal glands absent. Cephalic end narrowed, conic pointed, 7-8 $\mu \mathrm{m}$ wide. Cephalic cap present. Lips and labial sensillae absent. Four cephalic setae short, about $1 \mu \mathrm{m}$ long. Amphidial fovea longitudinal stretched, without dorsal bend of loop, 30-32 $\mu \mathrm{m}$ long. Amphidial fovea gradually transited in to lateral fields. Lateral fields in shape of thin, winding line, which extended to tail terminus. Mouth situated sub terminally, dorsally. Oesophagus slightly muscular, gradually extended to its basis, but not formed bulb. Cardia small. Renette body sack-shaped, 17-20 $\mu \mathrm{m}$ long, situated in intestine beginning. Rectum about 0.8 times as long as anal body diameter.

Gonads twin, opposited, outstretched. Vulva in shape of longitudinal slit, praequatorial. Vulvar lips not sclerotized, no protruding outside the body counter. Vagina short, straight, with thin walls. Spermateca and vulvar glands not observed. Uterus spacious. Tail elongateconical, gradually narrowing. Tail terminus with subterminal setae. Caudal setae absent. Caudal glands and spinneret well developed.

\section{Male: Unknown.}

Type locality a habitat: Coast area of the West sea of Vietnam, latitude $8^{\circ} 38^{\prime} 58.53^{\prime} ' \mathrm{~N}$, longitude $105^{\circ} 1$ ' $1.28^{\prime}$ ' $\mathrm{E}$, depth $4 \mathrm{~m}$, finely silt.

Type material: Holotype, female on slide number 73/III deposited at the nematode collection of the Institute of Inland Water Biology, Borok, Russia. Paratype, one female deposited at the nematode collection of the Institute of Inland Water Biology, Borok, Russia.

Differential diagnosis: Campylaimus gracilis sp. n. morphologicaly resembles to C. minor Timm, 1961, but has the another shape of amphidial fovea, another position of mouth (mouth situated subtermally, ventrally in C. minor), longer body ( $\mathrm{L}=0.384 \mu \mathrm{m}$ in C. minor) and shorter cephalic setae (cephalic setae $2 \mu \mathrm{m}$ long or $22 \%$ of the head diameter in C. minor) [3].

Etymology: The species name means "graceful", "elegant". 

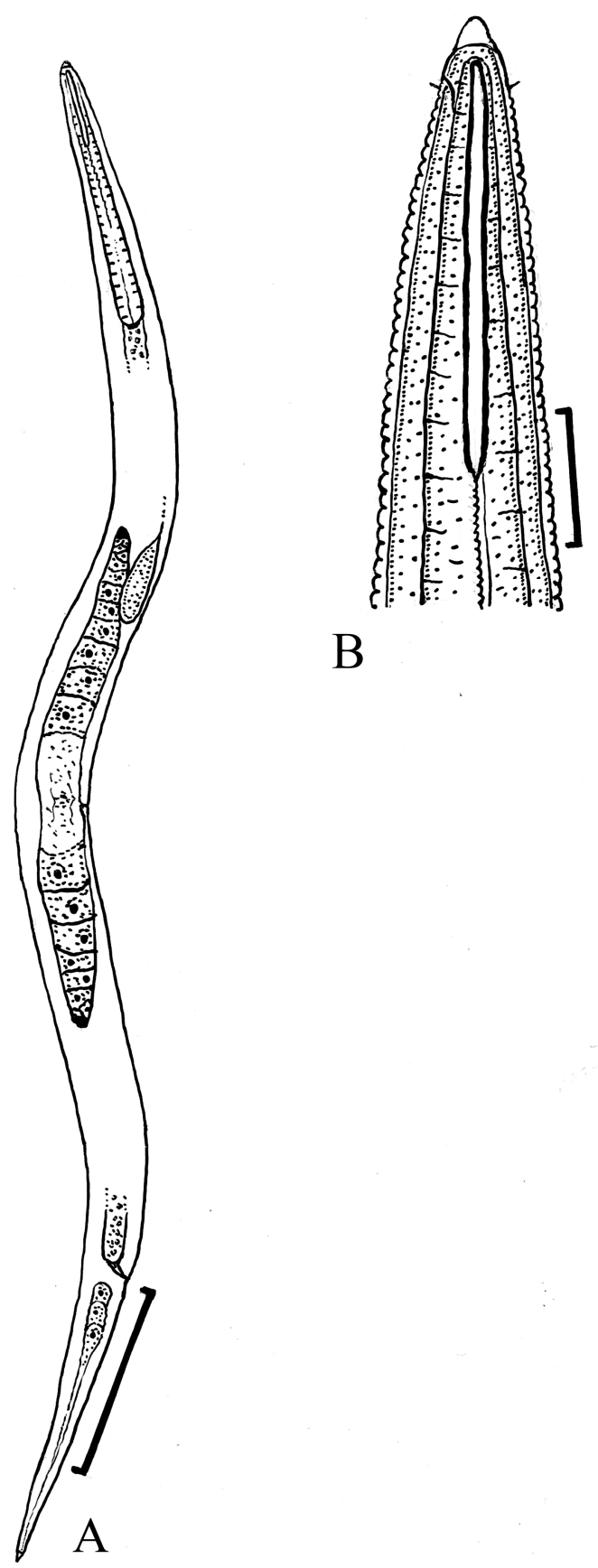

Figure 2. Campylaimus gracilis sp. n. (female)

A. Entire body; B. Head; C. Tail. Scale bars: A - $40 \mu \mathrm{m}$; C - $15 \mu \mathrm{m}$; B - $10 \mu \mathrm{m}$.

\section{REFERENCES}

1. Cobb N. A., 1920. One hundred new nemas type species of 100 new genera). Contribution to a Science of Nematology (Baltimore), 9: 217-343.
2. Gerlach S. A., 1962. Freilebende Meeresnematoden von der Malediven. Kieler Meeresforschungen, 18: 81-108.

3. Timm R. W., 1961. The marine nematodes of the Bay of Bengal. Proceedings of the Pakistan Academy of Science, 1(1): 1-84. 


\title{
HAI LOÀI TUYẾN TRÙNG MỚI THUỘC HỌ DIPLOPELTIDAE FILIPJEV, 1918 Ở VÙNG BIỂN VEN BỜ VIÊT NAM
}

\author{
Nguyễn Vũ Thanh ${ }^{1}$, Nguyễn Thanh Hiền ${ }^{1}$, Gagarin V. G \\ ${ }^{(1)}$ Viện Sinh thái và Tài nguyên sinh vật \\ ${ }^{(2)}$ Viện Sinh học nước nội địa, Viện Hàn lâm Khoa học Liên bang Nga
}

\section{TÓM TẮT}

Hai loài tuyến trùng sống tự do ở vùng nước ven bờ Biển Tây Nam (Vịnh Thái Lan) đã được phát hiện và mô tả. Loài tuyến trùng mới Diplopeltula obesa $\mathrm{sp}$. $\mathrm{n}$. khác biệt với các loài đã biết trong giống này bởi cơ thể ngắn và dày, với đuôi tương đối dài và các lông trên môi ngắn. Loài tuyến trùng Campylaimus gracilis $\mathrm{sp}$. $\mathrm{n}$. về hình thái tương đối giống loài $C$. minor Timm, 1961, song khác bởi có cấu tạo lỗ amphid khác biệt, vị trí, hình dáng của xoang miệng khác hơn, cơ thể dài hơn và các lông cứng trên miệng ngắn hơn.

Tù khóa: Araeolaimida, Campylaimus, Diplopeltula, loài mới, biển Đông, vùng biển ven bờ Việt Nam.

Ngày nhận bài: 29-11-2011 